\title{
Vibrio aestuarianus: a New Species from Estuarine Waters and Shellfish $\dagger$
}

\author{
DAVID L. TISON $¥ *$ AND RAMON J. SEIDLER \\ Department of Microbiology, Oregon State University, Corvallis, Oregon 97331
}

\begin{abstract}
A group of phenotypically similar bacteria were isolated from estuarine waters and shellfish from the Oregon coast by procedures designed for the isolation of potentially pathogenic Vibrio species. Although these strains were typical of bacteria of the genus Vibrio, they could be distinguished from previously described species by their arginine dihydrolase activities, negative Voges-Proskauer reactions, fermentation of sucrose and lactose, and inability to grow in 0 or $>5 \%$ added $\mathrm{NaCl}$. The deoxyribonucleic acid base compositions of these strains ranged from 43 to $44 \mathrm{~mol} \%$ guanine plus cytosine. There was $>85 \%$ deoxyribonucleic acid relatedness among these strains (melting temperature $-15^{\circ} \mathrm{C}$; membrane filter competition method), whereas there was $<25 \%$ relatedness with other Vibrio species, including Vibria anguillarum, Vibrio nereis, and Vibrio splendi$d u s$, which are also arginine dihydrolase positive and have similar guanine-pluscytosine contents. Our results indicate that the strains which we studied are distinct from previously described species of the genus Vibrio, and we propose the name Vibrio aestuarianus for these strains, indicating their estuarine origin. The type strain is strain OY-0-002 (= ATCC 35048).
\end{abstract}

The recent realization that Vibrio species pathogenic to humans were endemic to United States coastal waters has led to a renaissance in the study of the ecology, pathogenicity, and taxonomy of these bacteria. This renewed effort has led to the recent reorganization of the genus Vibrio (2) and to descriptions of a number of new species $(3-5,7,8,10)$.

During the course of a survey to determine the distribution of pathogenic Vibrio spp. in estuarine waters and shellfish from the coast of Oregon (D. L. Tison, M. Nishibuchi, and R. J. Seidler, Abstr. Annu. Meet. Am. Soc. Microbiol. 1981, Q97, p. 216), phenotypically similar bacteria which were distinct from previously described Vibrio species were isolated. Comparisons with other lactose-fermenting Vibrio species indicated that the arginine dihydrolase-positive, lactose-positive strains isolated from Oregon estuaries were probably a new Vibrio species (11).

In this paper we describe the characteristics of these strains and show that these bacteria were genetically distinct from other phenotypically similar Vibrio species, thereby warranting their designation as a new species, Vibrio aestuarianus (formerly called "Vibrio aestuarii" [Tison and Seidler, Abstr. Annu. Meet. Am. Soc. Microbiol. 1983, I53, p. 148]).

+ Technical paper 6818 of the Oregon State University Agricultural Experiment Station.

$\ddagger$ Present address: Clinical Laboratories, The University of Texas Medical Branch, Galveston, TX 77550.

\section{MATERIALS AND METHODS}

Bacterial strains. Strains from water and shellfish from the Oregon coast were isolated by inoculating alkaline peptone broth and subsequently plating and isolating the organisms on thiosulfate-citrate-bile saltssucrose agar (Oxoid) (6). The sources of $V$. aestuarianus and the reference strains used in this study are listed in Table 1.

Phenotypic and genetic characterization. The media and methods used in phenotypic characterizations, deoxyribonucleic acid (DNA) base composition determinations, and DNA-DNA hybridization studies were essentially as described previously $(12,13)$.

\section{RESULTS AND DISCUSSION}

Vibrio aestuarianus sp. nov. The type strain of $V$. aestuarianus (aes.tu.a.ri.a'nus. L.n. aestuarium estuary; N.L. masc. adj. aestuarianus pertaining to an estuary) is strain OY-0-002 (= ATCC 35048). $V$. aestuarianus is a gram-negative, oxidase-positive, straight or curved, rodshaped bacterium which is motile by means of a single polar flagellum. Cells are about $0.5 \mu \mathrm{m}$ wide and 1.5 to $2.0 \mu \mathrm{m}$ long when they are Gram stained. $V$. aestuarianus grows without swarming on Trypticase soy, blood, thiosulfate-citratebile salts-sucrose, and MacConkey agars containing $0.5 \% \mathrm{NaCl}$. No growth is observed in media lacking $\mathrm{NaCl}$. The type strain and six of eight other strains failed to grow in media containing $7 \% \mathrm{NaCl}$. Growth is optimal at 20 to $25^{\circ} \mathrm{C}$ but also occurs at 5 and $37^{\circ} \mathrm{C}$ but not $42^{\circ} \mathrm{C}$. $V$. aestuarianus is facultatively anaerobic and pro- 
TABLE 1. DNA relatedness of $V$. aestuarianus $\mathrm{OY}-0-002^{\mathrm{T}}$ to other $V$. aestuarianus strains and to other strains of Vibrionaceae

\begin{tabular}{|c|c|c|}
\hline Source of unlabeled DNA ${ }^{a}$ & Origin or source of strain ${ }^{a}$ & $\begin{array}{c}\% \\
\text { Relatedness }^{b}\end{array}$ \\
\hline \multicolumn{3}{|l|}{ V. aestuarianus } \\
\hline OSU OY $-0-002^{\mathrm{Tc}}$ & Oyster; Yaquina Bay, Oreg. & 100 \\
\hline OSU OY-0-003 & Oyster; Puget Sound, Wash. & 86 \\
\hline OSU OY-0-004 & Oyster; Puget Sound, Wash. & 100 \\
\hline OSU WA-0-034 & Water; Netarts Bay, Oreg. & 98 \\
\hline OSU WA-0-035 & Water; Tillamook Bay, Oreg. & 84 \\
\hline OSU OY-0-006 & Oyster; Coos Bay, Oreg. & 93 \\
\hline OSU CL-0-004 & Clam; Coos Bay, Oreg. & 87 \\
\hline OSU CR-0-002 & Crab; Tillamook Bay, Oreg. & 94 \\
\hline OSU CR-0-006 & Crab; Tillamook Bay, Oreg. & $\mathrm{ND}^{d}$ \\
\hline \multicolumn{3}{|l|}{ Vibrio spp. } \\
\hline UNCC 1077 & J. Oliver & 16 \\
\hline UNCC 1084 & J. Oliver & 27 \\
\hline UNCC 1085 & J. Oliver & 27 \\
\hline V. alginolyticus ATCC $17749^{\mathrm{T}}$ & ATCC & 19 \\
\hline V. anguillarum OSU LS174 & J. Rohovec & 19 \\
\hline V. cholerae CDC E7323 & $\mathrm{CDC}$ & 2 \\
\hline$V$. damsela CDC $2588-80^{\mathrm{T}}$ & D. Fisher & 14 \\
\hline V. diazotrophicus UMD NS1 ${ }^{\mathrm{T}}$ & P. West & 0 \\
\hline V. fluvialis UMD 2386 & R. Colwell & 0 \\
\hline$V$. nereis ATCC $25917^{\mathrm{T}}$ & ATCC & 17 \\
\hline V. ordalii OSU 21 & J. Rohovec & 11 \\
\hline V. parahaemolyticus CDC A8659 & J. Baross & 10 \\
\hline V. splendidus ATCC $33125^{\mathrm{T}}$ & ATCC & 24 \\
\hline V. vulnificus ATCC $27562^{\mathrm{T}}$ & ATCC & 20 \\
\hline Aeromonas hydrophila NMRI 7 & S. Joseph & 0 \\
\hline
\end{tabular}

${ }^{a}$ OSU, Oregon State University culture collection; UNCC, University of North Carolina at Charlotte culture collection; ATCC, American Type Culture Collection; CDC, Centers for Disease Control culture collection; UMD, University of Maryland culture collection; NMRI, Naval Medical Research Institute culture collection.

${ }^{b}$ Experiments were conducted under supraoptimal conditions (melting temperature $-15^{\circ} \mathrm{C}$ ).

$c \mathrm{~T}=$ type strain.

${ }^{d}$ ND, DNA relatedness was not determined (this strain was used in phenotypic studies only).

duces beta-hemolysis on sheep blood agar, indole, catalase, gelantinase, deoxyribonuclease, ortho-nitrophenyl- $\beta$-D-galactopyranosidase, and arginine dihydrolase. Lysine decarboxylase, ornithine decarboxylase, collagenase, and elastase are not produced. No strain tested produced luminescence on marine agar, acetoin (VogesProskauer test), or $\mathrm{H}_{2} \mathrm{~S}$. All $V$. aestuarianus strains tested produced acid without gas in less than $72 \mathrm{~h}$ at $37^{\circ} \mathrm{C}$ from $\mathrm{D}$-amygalin, D-glucose, lactose, D-mannitol, D-mannose, sorbitol, sucrose, and trehalose. The type strain and most of the other strains tested produced acid from cellobiose (seven of nine strains), glycerol (eight of nine strains), and melibiose (seven of nine strains). No strain produced acid from adonitol, L-arabinose, dulcitol, raffinose, L-rhamnose, salicin, or xylose. The key characteristics of $V$. aestuarianus are shown in Table 2.

Antimicrobial susceptibility. All $V$. aestuarianus strains tested were susceptible to vibriostatic agent $0 / 129(10-\mu \mathrm{g}$ disk) and to amikacin, ampicillin, carbenicillin, cephalothin, colistin, chloramphenicol, gentamicin, kanamycin, nitrofurantoin, tetracycline, tobramycin, and tri- methoprim-sulfamethoxazole at standard concentrations with the disk diffusion method (1).

DNA base composition. The DNA base composition of the $V$. aestuarianus type strain is 43.2 mol\% guanine plus cytosine. The DNA base compositions of the eight other strains tested range from 43 to $44 \mathrm{~mol} \%$ guanine plus cytosine.

DNA relatedness. The results of DNA-DNA competition experiments conducted under supraoptimal conditions (melting temperature $-15^{\circ} \mathrm{C}$ ) (Table 1) show that the nine estuarine isolates represent a genetic species with $\geqq 84 \%$ relatedness to $V$. aestuarianus type strain OY-0002 . The $V$. aestuarianus type strain was found to be genetically distinct $(<25 \%$ relatedness) from other Vibrio species with similar DNA base compositions and the type or reference strains of phenotypically similar species (Vibrio anguillarum, Vibrio damsela, Vibrio diazotrophicus, Vibrio nereis and Vibrio spendidus). Generally, DNAs from strains of the same species are $\geqq 60 \%$ related under supraoptimal reassociation conditions (melting temperature $-15^{\circ} \mathrm{C}$ in this case), whereas species within the same genus are usually $<30 \%$ related under supraoptimal 
TABLE 2. Characteristics useful for distinguishing $V$. aestuarianus from other arginine dihydrolase-positive Vibrio species $^{a}$

\begin{tabular}{|c|c|c|c|c|c|c|c|c|c|c|c|}
\hline \multirow[b]{2}{*}{ Species } & \multirow{2}{*}{$\begin{array}{l}\text { Oxi- } \\
\text { dase }\end{array}$} & \multirow{2}{*}{$\begin{array}{l}\text { Lumines- } \\
\text { cence }\end{array}$} & \multirow{2}{*}{$\begin{array}{c}\text { Voges- } \\
\text { Proskauer } \\
\text { test }\end{array}$} & \multirow[b]{2}{*}{ Indole } & \multirow[b]{2}{*}{ Citrate } & \multirow{2}{*}{$\begin{array}{c}\text { Gelatin } \\
\text { hydro- } \\
\text { lysis }\end{array}$} & \multirow{2}{*}{$\begin{array}{c}\text { Gas } \\
\text { from } \\
\text { glucose }\end{array}$} & \multicolumn{3}{|c|}{ Acid from: } & \multirow{2}{*}{$\begin{array}{c}\text { Guanine-plus- } \\
\text { cytosine } \\
\text { content } \\
(\mathrm{mol} \%)\end{array}$} \\
\hline & & & & & & & & $\begin{array}{l}\text { Arab- } \\
\text { inose }\end{array}$ & $\begin{array}{l}\text { Lac- } \\
\text { tose }\end{array}$ & $\begin{array}{l}\text { Suc- } \\
\text { rose }\end{array}$ & \\
\hline V. aestuarianus & $+^{h}$ & - & - & + & + & + & - & - & + & + & $43-44$ \\
\hline V. anguillarum & + & - & + & $\mathrm{v}$ & - & + & - & v & - & + & $44-46$ \\
\hline$V$. costicola & + & - & - & - & - & $\mathrm{V}$ & - & - & - & + & 50 \\
\hline V. damsela & + & - & + & - & - & - & + & - & - & - & 44 \\
\hline V. diazotrophicus & + & - & - & + & + & - & - & + & + & + & $45-47$ \\
\hline V. fluvialis & + & - & - & - & $\mathrm{v}$ & + & v & + & - & + & $50-51$ \\
\hline V. metschnikovii & - & - & + & $\mathrm{v}$ & $\mathbf{v}$ & + & - & - & $\mathrm{v}$ & + & $44-47$ \\
\hline$V$. nereis & + & - & - & + & - & + & - & - & - & + & $46-47$ \\
\hline V. proteolyticus & + & - & + & + & + & + & - & - & - & - & 50 \\
\hline V. splendidus & + & + & - & + & + & + & - & - & - & $v$ & $45-46$ \\
\hline
\end{tabular}

${ }^{a}$ The characteristics of $V$. aestuarianus, $V$. anguillarum, and $V$. fluvialis are based on data from this study. Literature descriptions were used for $V$. damsela (8), V. diazotrophicus (4), and $V$. costicola, V. metschnikovii, $V$. nereis, V. proteolyticus, and V. splendidus (P. Baumann, A. L. Furniss, and J. V. Lee, manuscript in preparation).

${ }_{b}+$, Positive; -, negative; v, variable.

reassociation conditions (3). Under optimal conditions for hybridization (melting temperature $-25^{\circ} \mathrm{C}$ ), the relatedness value between species (e.g., between $V$. aestuarianus and Vibrio alginolyticus) may increase to as much as 50 to $60 \%$, but it would still be less than that observed between strains within a species.

Vibrio sp. strains UNCC 1077, UNCC 1084, and UNCC 1085, which were isolated from the southeastern United States coast, were included in the DNA homology studies because these strains were phenotypically similar to $V$. aestuarianus and to strains grouped in cluster III in the numerical taxonomy study of lactose-fermenting marine vibrios by Oliver et al. (9). Strains UNCC 1077, UNCC 1084, and UNCC 1085 were not genetically related to $V$. aestuarianus at the species level (Table 1). An extensive phenotypic characterization of these strains and the strains in cluster III described by Oliver et al. (9) indicated that the strains isolated from the southeastern United States coast are probably $V$. diazotrophicus, a recently described species capable of nitrogen fixation (4).

$V$. aestuarianus is easily distinguished from pathogenic lactose-fermenting Vibrio spp. by its arginine dihydrolase activity and lack of ornithine and lysine decarboxylases. Vibrio cholerae and Vibrio vulnificus may also ferment lactose; however, these species lack arginine dihydrolase activity and usually decarboxylate lysine and ornithine. Characteristics which are useful in distinguishing $V$. aestuarianus from other arginine dihydrolase-positive Vibrio species are given in Table 2.

The public health significance of $V$. aestuarianus remains to be determined. However, the association of this species with crabs, clams, and oysters warrants an investigation into the potential of $V$. aestuarianus strains as not only shellfish pathogens but also human pathogens since raw or improperly cooked shellfish serve as vehicles of infection by other pathogenic Vibrio species.

\section{ACKNOWLEDGMENTS}

We thank John Greenwood and Mitsauki Nishibuchi for assistance in the field and preliminary characterization of the $V$. aestuarianus strains. Other bacterial strains were kindly furnished by John Baross, Rita Colwell, Dixie TeebkenFisher, Howard Hada, Sam Joseph, Jim Oliver, John Rohovec, and Paul West. Paul Baumann furnished information on the status of Vibrio taxonomy, and T. O. MacAdoo provided etymological assistance for which we are grateful.

This work was sponsored by the Oregon State University Sea Grant College Program, which is supported by the National Oceanic and Atmospheric Administration Office of Sea Grant, U.S. Department of Commerce, under grant NA79AAD-00106, project R/FSD8.

\section{LITERATURE CITED}

1. Barry, A. L., and C. Thornsberry. 1980. Susceptibility testing: diffusion test procedures, p. 463-464. In E. H. Lenette, A. Ballows, W. J. Hausler, Jr., and J. P. Truant (ed.), Manual of clinical microbiology, 3rd ed. American Society for Microbiology, Washington, D.C.

2. Baumann, P., L. Baumann, S. S. Bang, and M. J. Woolkalis. 1980. Reevaluation of the taxonomy of Vibrio, Beneckea and Photobacterium: abolition of the genus Beneckea. Curr. Microbiol. 4:127-132.

3. Davis, B. R., G. R. Fanning, J. M. Madden, A. G. Steigerwalt, H. B. Bradford, Jr., H. L. Smith, Jr., and D. J. Brenner. 1981. Characterization of biochemically atypical Vibrio cholerae strains and designation of a new pathogenic species, Vibrio minicus. J. Clin. Microbiol. 14:631639.

4. Guerinot, M. L., P. A. West, J. V. Lee, and R. R. Colwell. 1982. Vibrio diazotrophicus sp. nov., a marine nitrogenfixing bacterium. Int. J. Syst. Bacteriol. 32:350-357.

5. Hickman, F. W., J. J. Farmer III, D. G. Hollis, G. R. Fanning, A. G. Steigerwalt, R. E. Weaver, and D. J. Brenner. 1982. Identification of Vibrio hollisae sp. nov. from patients with diarrhea. J. Clin. Microbiol. 15:395-401.

6. Kaper, J. B., H. Lockman, R. R. Colwell, and S. W. Joseph. 1979. Ecology, serology, and enterotoxin produc- 
tion of Vibrio cholerae in Chesapeake Bay. Appl. Environ. Microbiol. 37:91-103.

7. Lee, J. V., P. Shread, A. L. Furniss, and T. Bryant. 1981. Taxonomy and description of Vibrio flavialis sp. nov. (synonym group $\mathrm{F}$ vibrios, group EF-6). J. Appl. Bacteriol. 50:73-95.

8. Love, M., D. Teebken-Fisher, J. E. Hose, J. J. Farmer III, F. W. Hickman, and G. R. Fanning. 1981. Vibrio damsela, a marine bacterium, causes skin ulcers on the damselfish Chromic punctipinnis. Science 214:1139-1140.

9. Oliver, J. D., R. A. Warner, and D. R. Cleland. 1982 Distribution and ecology of Vibrio vulnificus and other lactose-fermenting marine vibrios in coastal waters of the southeastern United States. Appl. Environ. Microbiol. 44:1404-1414.
10. Schiewe, M. H., T. J. Trust, and J. H. Crosa. 1981. Vibrio ordalii $\mathrm{sp}$. nov.: a causative agent of vibriosis in fish. Curr. Microbiol. 6:343-348.

11. Tison, D. L., J. D. Greenwood, M. Nishibuchi, and R. J. Seidler. 1983. Molecular taxonomy of lactose-fermenting vibrios, p. 217-237. In R. R. Colwell (ed.), Vibrios in the environment. John Wiley \& Sons, Inc., New York.

12. Tison, D. L., M. Nishibuchi, J. D. Greenwood, and R. J. Seidler. 1982. Vibrio vuinificus biogroup 2: new biogroup pathogenic for eels. Appl. Environ. Microbiol. 44:640646.

13. Tison, D. L., and R. J. Seidler. 1981. Genetic relatedness of clinical and environmental isolates of the lactosepositive Vibrio vulnificus. Curr. Microbiol. 6:181-184. 